\title{
MEKANISME DIABETES MELITUS TIPE 2 DALAM MENINGKATKAN RISIKO PENYAKIT KATARAK
}

\author{
Adellia Risda Sativa ${ }^{1}$
}

${ }^{1}$ Fakultas Kedokteran, Universitas Lampung

\begin{abstract}
Mechanism of Type 2 Diabetes Mellitus in Increasing Risk of Cataract Disease. In 2010, there were 94 million people with visual impairment and 20 million people who were blind due to cataract. cataract is the loss of transparency of the lens in the eye due to hydration of lens fluid and lens protein denaturation. Many risk factors can affect the occurrence of cataracts, one of which is a systemic disease. The International Diabetes Federation (IDF) estimated in 2017 there were 451 million diabetes mellitus patients worldwide and will increase to 693 million by 2045. Type 2 diabetes mellitus increases the risk of cataracts through the polyol pathway. Sorbitol production that catalyzed by aldose reductase (AR) in diabetic patients is faster than the amount of sorbitol that is converted to fructose by sorbitol dehydrogenase, and secretion of sorbitol through diffusion is blocked by the polar nature of sorbitol resulting in the accumulation of sorbitol in the intracellular. Increased intracellular accumulation of sorbitol leads to hyperosmotic effect that results in degeneration of the lens fibers. Osmotic stress resulting from the accumulation of sorbitol induces stress in the endoplasmic reticulum (ER) and cause oxidative stress damage to lens fibers.
\end{abstract}

Keyword: Cataract, Hyperosmotic, Osmotic Stress, Type 2 Diabetes Mellitus

\begin{abstract}
Abstrak: Mekanisme Diabetes Melitus Tipe 2 Dalam Meningkatkan Risiko Penyakit Katarak. Pada tahun 2010, terdapat 94 juta orang yang mengalami gangguan penglihatan dan 20 juta orang mengalami kebutaan karena katarak. katarak merupakan hilangnya transparansi lensa mata akibat hidrasi cairan lensa maupun denaturasi protein lensa. Banyak faktor risiko yang dapat mempengaruhi terjadinya katarak, salah satunya adalah penyakit sistemik. International Diabetes Federation (IDF) memperkirakan bahwa pada tahun 2017 terdapat 451 juta pasien diabetes melitus diseluruh dunia dan akan menjadi 693 juta pada tahun 2045. Diabetes melitus tipe 2 meningkatkan risiko katarak melalui jalur poliol. Produksi sorbitol yang dikatalisis oleh Enzim aldose reduktase (AR) pada pasien diabetes lebih cepat dibandingkan dengan banyaknya sorbitol yang dikonversi menjadi fruktosa oleh enzim sorbitol dehidrogenase, selain itu pengeluaran sorbitol melalui difusi yang terhalang oleh sifat polar sorbitol mengakibatkan penumpukan sorbitol di intraseluler. Peningkatan akumulasi sorbitol intraseluler menyebabkan terjadinya efek hiperosmotik yang menghasilkan degenerasi serat lensa. Stres osmotik yang terjadi karena akumulasi sorbitol menyebabkan stres pada retikulum endoplasma kemudian membentuk stres oksidatif yang merusak serat lensa.
\end{abstract}

Kata kunci: Diabetes Melitus tipe 2, Hiperosmotik, Katarak, Stres Osmotik

\section{PENDAHULUAN}

Katarak masih menjadi penyebab terbanyak pada kebutaan dan penyebab terbanyak kedua pada gangguan penglihatan. Berdasarkan estimasi global tahun 2010, terdapat 94 juta orang yang mengalami gangguan penglihatan dan 20 juta orang mengalami kebutaan karena katarak. Katarak bertanggung jawab terhadap
$51 \%$ kebutaan yang terjadi di dunia (Song, Wang, Theodoratou, Chan, \& Rudan, 2018). Insiden katarak di indonesia diperkirakan sebesar $0,1 \% /$ tahun atau di antara 1.000 orang terdapat seorang penderita baru katarak setiap tahunnya (Kementrian Kesehatan Republik Indonesia, 2014).

Katarak merupakan hilangnya transparansi lensa mata atau terjadi 
kekeruhan pada lensa akibat hidrasi cairan lensa, denaturasi protein lensa atau akibat keduanya (Nadyanti, Himayani, Putri, \& Yusran, 2019). Kekeruhan yang terdapat di dalam lensa menyebabkan berkurangnya cahaya yang masuk dan mengganggu penglihatan. Katarak sering dideskripsikan seperti melihat air terjun atau kertas lilin (Gupta, Rajagopala, \& Ravishankar, 2019). Katarak dapat mengganggu aktivitas sehari-hari, membuat penderitanya mengalami depresi, lebih mudah terjatuh, dan meningkatkan kematian (Chew et al., 2012). Berdasarkan beberapa studi populasi diperoleh bahwa prevalensi katarak meningkat seiring dengan pertambahan usia. Prevalensi katarak pada pria adalah $6,71 \%$ untuk umur $45-$ 49 tahun dan $73,01 \%$ untuk umur $85-89$ tahun. Sedangkan pada wanita prevalensi katarak yaitu $8,39 \%$ untuk umur 45-49 dan 77,51\% untuk umur 8589 tahun. Katarak dapat menyebabkan gangguan penglihatan dan berkurangnya kualitas hidup (Song et al., 2018).

Diabetes melitus tipe 2 adalah penyakit sistemik kronis yang ditandai dengan hiperglikemia serta terdapat gangguan metabolisme karbohidrat, lemak, dan protein akibat kekurangan kerja dan atau sekresi insulin. Penderita diabetes melitus dapat memiliki gejala seperti polidipsia, polifagia, poliuria, kesemutan dan penurunan berat badan (Fatimah, 2015). Prevalensi diabetes melitus semakin lama semakin meningkat. International Diabetes Federation (IDF) memperkirakan bahwa pada tahun 2017 ada 451 juta pasien DM diseluruh dunia dan akan menjadi 693 juta pasien DM pada tahun 2045 (Nadyanti et al., 2019). Menurut WHO, Indonesia menduduki peringkat kedua dengan prevalensi DM terbanyak di Asia Tenggara. Sebanyak $90 \%$ pasien DM memiliki diabetes melitus tipe 2 (Sugiharto, Hsu, Toobert, \& Wang, 2019).

Diabetes melitus tipe 2 dapat menyebabkan kerusakan struktur jaringan mata. Gangguan penglihatan pada pasien DM paling sering disebabkan oleh katarak dikarenakan oleh semakin meningkatnya insidensi dan progresifitas pasien DM yang mengalami katarak.
Pasien DM dilaporkan memiliki risiko 5 kali lebih besar untuk dapat menderita katarak. Beberapa studi menunjukkan bahwa katarak terjadi sebanyak 3 sampai 4 kali lebih sering pada pasien DM yang berumur kurang dari 65 tahun dan 2 kali lebih sering terjadi pada pasien yang berumur lebih dari 65 tahun. Jalur poliol dikatakan memainkan peran dalam perkembangan katarak pada pasien DM. Pada pasien DM terdapat mekanisme terbentuknya poliol dari glukosa oleh enzim Aldose Reductase (AR) yang menghasilkan peningkatan stres osmotik pada serat lensa kemudian menyebabkan ruptur dan penebalan pada serat lensa yang memicu terjadinya katarak (Kiziltoprak, Tekin, Inanc, \& Goker, 2019).

Diabetes dan katarak merupakan beban kesehatan dan ekonomi yang sangat besar, terutama bagi negara berkembang yang belum memiliki penanganan diabetes yang baik dan akses operasi katarak yang masih sulit. Pendekatan lain untuk mengatasi kebutaan akibat katarak mulai dilakukan dengan cara mengetahui mekanisme terjadinya katarak karena diabetes melitus tipe 2 sehingga perkembangan katarak dapat dicegah maupun ditunda sejak dini (Pollreisz \& Schmidt-erfurth, 2010).

\section{METODE}

Dengan cara mengumpulkan artikel ilmiah penelitian sebelumnya untuk mendapatkan informasi dan membuat ringkasan berupa review artikel ilmiah.

\section{HASIL DAN PEMBAHASAN}

Lensa mata merupakan struktur kristalin yang transparan dan bikonveks pada mata manusia serta memiliki fungsi mirip seperti lensa pada kamera. Kristalin adalah protein yang menyusun lensa dan bertanggung jawab dalam fungsi refraksi lensa mata. Pada keadaan katarak, lensa mata mengalami penurunan transparansi dan peningkatan kekeruhan atau berkabut. Modifikasi, agregasi, dan presipitasi kristalin adalah mekanisme utama yang mendasari perkembangan katarak (Lam et al., 2015). 
Terdapat beberapa tipe katarak. Tipe yang pertama adalah katarak senilis, katarak ini berhubungan dengan bertambahnya umur dan merupakan katarak yang paling umum, biasanya tipe ini berkembang saat seseorang mencapai umur diatas 50 tahun. Tipe kedua adalah katarak pada anak-anak yang terbagi menjadi dua, yaitu katarak kongenital yang sudah terjadi saat lahir dan katarak juvenil yang berkembang setelah lahir. Kedua jenis katarak ini disebabkan oleh kondisi genetik, congenital disorder maupun infeksi intrauterin. Tipe selanjutnya yaitu katarak sekunder, katarak ini adalah tipe katarak yang dapat terjadi karena trauma atau operasi pada mata, penyakit lain pada mata (seperti glaukoma atau infeksi mata), berbagai obat-obatan (seperti kortikosteroid), paparan radiasi, dan penyakit sistemik (seperti diabetes melitus). Katarak juga dapat diklasifikasikan secara morfologis yaitu katarak subkapsular, katarak nuklear dan katarak kortikal (Lam et al., 2015).

Banyak faktor risiko yang dapat mempengaruhi terjadinya katarak. Faktor risiko yang paling umum adalah usia. semakin bertambahnya usia akan semakin meningkatkan risiko terjadinya katarak. Selain itu ada beberapa faktor lainnya seperti rendahnya tingkat pendidikan, rendahnya status sosial ekonomi, jenis kelamin wanita, etnik tertentu (orang Asia lebih tinggi risikonya dibandingkan orang Eropa), faktor genetik, paparan sinar UV-B, merokok, konsumsi alkohol, malnutrisi, dan berbagai penyakit sistemik seperti hipertensi, gangguan ginjal, hipokalsemia dan diabetes melitus tipe 2 yang dapat menyebabkan katarak kortikal dan katarak subkapsular posterior (Liu, Wilkins, Kim, Malyugin, \& Mehta, 2017). Orang yang memiliki katarak memiliki gejala yang berbedabeda karena tipe katarak yang beragam. Pasien sering mengeluhkan penglihatan kabur dan merasa silau serta mengalami fenomena optis. Pasien juga dapat mengeluhkan penglihatan seperti berasap disertai dengan penurunan penglihatan yang progresif (Ilyas \& Yulianti, 2017). Katarak nuklear sering kali mempengaruhi penglihatan jauh dibandingkan dengan penglihatan dekat. Sedangkan katarak subkapsular posterior seringkali mempengaruhi penglihatan dekat dibandingkan penglihatan jauh. Katarak subkapsular posterior sering membuat penderitanya mengalami silau (Liu et al., 2017).

Terapi standar untuk katarak adalah operasi dengan menghilangkan lensa yang mengalami katarak dan diganti dengan lensa intraokular (Liu et al., 2017). Penghilangan lensa yang mengalami katarak atau bisa disebut ekstraksi katarak dapat dilakukan secara intrakapsular yaitu mengeluarkan lensa bersama dengan kapsul lensa atau ekstrakapsular yaitu mengeluarkan isi lensa (korteks dan nukleus) melalui kapsul anterior yang dirobek dengan meninggalkan kapsul posterior (Ilyas \& Yulianti, 2017). Peningkatan teknologi dan teknik pada operasi katarak dalam beberapa dekade terakhir memberikan hasil operasi katarak yang baik. Selain itu dibutuhkan juga penilaian preoperatif, penentuan kekuatan lensa intraokular, manajemen intraoperatif, dan pasca operasi yang tepat (Liu et al., 2017).

Diabetes melitus tipe 2 adalah penyakit metabolik kronis yang ditandai dengan kenaikan gula darah karena terdapat gangguan fungsi insulin (resistensi insulin) dan atau penurunan sekresi insulin oleh sel beta pankreas. Perkembangan diabetes melitus tipe 2 awalnya menunjukan adanya gangguan pada sekresi insulin yang bersifat relatif, hal ini menandakan bahwa insulin gagal mengkompensasi resistensi insulin. Penanganan yang tidak baik akan membuat penyakit ini berkembang dan terjadi kerusakan sel-sel $B$ pankreas. Kerusakan progresif dari sel B pankreas akan menyebabkan defisiensi insulin sehingga penderita memerlukan insulin eksogen (Fatimah, 2015).

Terdapat banyak faktor risiko yang dapat mempengaruhi terjadinya diabetes melitus tipe 2. Faktor risiko yang paling penting adalah obesitas yang ditunjukkan dengan Indeks Massa Tubuh (IMT) $\geq 25 \mathrm{~kg} / \mathrm{m}^{2}$ atau lingkar perut $\geq 80$ $\mathrm{cm}$ pada wanita dan $\geq 90 \mathrm{~cm}$ pada lakilaki (Fatimah, 2015). Sebagian besar pasien diabetes melitus tipe 2 memiliki berat badan yang tergolong obesitas, 
obesitas menyebabkan fungsi insulin terganggu (resistensi insulin). Pasien yang tidak obesitas banyak ditemukan memiliki peningkatan persentase lemak tubuh yang banyak terdistribusi di regio abdomen. Pasien DM tipe 2 banyak yang tidak terdiagnosis selama bertahuntahun karena kondisi hiperglikemia yang dialami oleh pasien berkembang secara bertahap dan tidak cukup berat untuk membuat pasien menyadari gejala klasik diabetes (American Diabetes Association, 2010). Faktor risiko lainnya yang dapat diubah selain obesitas yaitu kurangnya aktivitas fisik, dislipidemia, diet yang tidak sehat, dan hipertensi. Sedangkan faktor risiko yang tidak dapat diubah yaitu riwayat keluarga dengan diabetes melitus, berumur $\geq 45$ tahun, etnik tertentu, riwayat lahir dengan berat badan rendah $(<2,5 \mathrm{~kg})$, dan riwayat melahirkan bayi dengan berat badan lahir bayi $>4000$ gram atau riwayat pernah menderita diabetes melitus gestasional (Fatimah, 2015).

Penderita diabetes melitus tipe 2 biasanya akan mengeluhkan gejala seperti banyak makan (poliphagia), banyak minum (polidipsia), banyak buang air kecil (poliuria), berat badan turun dengan cepat sebanyak 5-10 kg dalam waktu 2-4 minggu walaupun nafsu makan bertambah, dan mudah lelah. Gejala kronis juga dapat dikeluhkan seperti kesemutan, kulit terasa tertusuk-tusuk atau panas, kelelahan, gigi mudah goyah dan mudah lepas, dan penurunan kemampuan seksual bahkan dapat terjadi impotensi pada pria (Fatimah, 2015). Diagnosis diabetes melitus tipe 2 ditegakkan dengan melihat keluhan dan gejala yang khas ditambah hasil pemeriksaan glukosa darah sewaktu $>200 \mathrm{mg} / \mathrm{dl}$, atau glukosa darah puasa $>126 \mathrm{mg} / \mathrm{dl}$ (American Diabetes Association, 2010).

Pasien diabetes melitus tipe 2 ditatalaksana melalui pengaturan diet dengan menekankan pentingnya keteraturan makan dalam hal jadwal makan, jenis dan jumlah makanan terutama yang mengkonsumsi obat penurunan glukosa darah atau insulin. Diet yang dianjurkan adalah makanan dengan komposisi yang seimbang dalam hal karbohidrat $60-70 \%$, lemak $20-25 \%$ dan protein $10-15 \%$. Pasien dianjurkan melakukan latihan secara teratur yaitu 3-4 kali seminggu selama kurang lebih 30 menit yang sifatnya Continous, Rhytmical, Interval, Progresive, dan Endurance (CRIPE). Antidiabetik oral diindikasikan untuk menangani pasien DM tipe 2 ringan sampai sedang yang gagal dikendalikan dengan pengaturan diet dan olahraga. Obat golongan ini ditambahkan bila setelah 4-8 minggu upaya diet dan olahraga dilakukan, kadar gula darah tetap di atas $200 \mathrm{mg} / \mathrm{dl}$ dan $\mathrm{HbA} 1 \mathrm{C}$ di atas 8\% (Fatimah, 2015).

Perilaku atau gaya hidup dan faktor genetik adalah hal yang paling berpengaruh terhadap terjadinya diabetes melitus. Selain itu, lingkungan sosial dan pemanfaatan pelayanan kesehatan juga berkontribusi terhadap penanggulangan penyakit diabetes dan komplikasinya. Diabetes dapat memengaruhi berbagai sistem organ dalam tubuh sehingga diabetes dapat menyebabkan komplikasi makrovaskular dan mikrovaskular, komplikasi yang termasuk dalam komplikasi makrovaskular yaitu penyakit jantung, stroke, dan penyakit pembuluh daraf perifer. Penyakit pembuluh darah perifer dapat menyebabkan cedera yang sulit sembuh, gangren, bahkan panderitanya dapat menjalani amputasi. Sedangkan yang termasuk dalam komplikasi mikrovaskular yaitu kerusakan sistem saraf (neuropati), kerusakan sistem ginjal (nefropati), dan kerusakan mata (retinopati) (Rosyada \& Trihandini, 2013). Sebanyak $60 \%$ penderita yang sudah mengalami diabetes melitus tipe 2 selama lebih dari 20 tahun mengalami retinopati. Pada penderita diabetes terdapat perubahan komponen optik yaitu kornea, lensa, dan retina yang dipengaruhi oleh beberapa parameter seperti durasi menderita diabetes, level glukosa darah, dan penggunaan insulin (Pradhevi, Moegiono, \& Atika, 2012). Katarak adalah gangguan penglihatan yang paling umum terjadi pada pasien diabetes melitus. Peningkatan angka pasien DM tipe 2 juga akan meningkatkan insidensi katarak diabetik (Pollreisz \& Schmidt-erfurth, 2010). Katarak terbentuk lebih cepat pada orang yang menderita diabetes dan lebih mudah ditemukan 1,6 kali lebih sering dibandingkan dengan orang yang tidak 
mengalami diabetes (Pradhevi et al., 2012). Uji statistik menunjukkan bahwa risiko menderita katarak senilis pada responden yang memiliki riwayat diabetes melitus adalah 10,688 kali lebih besar dibandingkan responden yang tidak memiliki riwayat diabetes melitus (Hadini, Eso, \& Wicaksono, 2016).

Peningkatan kadar glukosa darah menimbulkan efek patologi pada jaringan tubuh yang tidak bergantung pada insulin untuk memasukkan glukosa ke dalam selnya, sehingga mereka tidak mampu mengatur transportasi glukosa seiring dengan meningkatnya konsentrasi gula pada ekstraseluler, misalnya pada lensa mata dan ginjal (Hadini et al., 2016). Katarak pada pasien diabetes berkembang melalui jalur poliol, enzim aldose reduktase (AR) mengkatalisis reduksi glukosa menjadi sorbitol yang mengakibatkan berkembangnya katarak. produksi sorbitol pada pasien diabetes lebih cepat dibandingkan dengan banyaknya sorbitol yang dikonversi menjadi fruktosa oleh enzim sorbitol dehidrogenase sehingga terjadi penumpukan sorbitol di intraseluler. Selain itu, pengeluaran sorbitol melalui difusi juga terhalang oleh sifat polar sorbitol. peningkatan akumulasi sorbitol intraseluler menyebabkan terjadinya efek hiperosmotik yang menyebabkan masuknya air ke dalam sel dan mengganggu gradien osmotik sehingga menghasilkan degenerasi serat lensa hidropik dan membentuk katarak (Kiziltoprak et al., 2019). Penelitian pada hewan menunjukkan bahwa akumulasi sorbitol intraselular karena enzim aldose reduktase (AR) menyebabkan keruntuhan serat lensa yang menghasilkan kekeruhan pada lensa (Nartey, 2017).

Stres osmotik yang terjadi karena akumulasi sorbitol menyebabkan stres pada retikulum endoplasma, yaitu tempat protein disintesis, yang pada akhirnya membentuk radikal bebas. Stres pada retikulum endoplasma juga disebabkan oleh fluktuasi level glukosa yang menginisiasi unfolded protein response (UPR) dan memproduksi oksigen reaktif sehingga menyebabkan stres oksidatif yang merusak serat lensa. Peningkatan level glukosa pada aqueous humor dapat menyebabkan glikasi pada protein lensa. Reaksi fenton yang dihasilkan oleh peningkatan level hidrogen peroksida $\left(\mathrm{H}_{2} \mathrm{O}_{2}\right)$ pada aqueous humor pasien DM juga menginduksi radikal hidroksil $\left(\mathrm{OH}^{-}\right)$setelah masuk ke dalam lensa. Faktor lain yang meningkat pada lensa dan aqueous humor pasien DM adalah radikal bebas nitrit oksida (NO) yang menyebabkan peningkatan pembentukan peroksinitrit, hal ini berkontribusi terhadap kerusakan sel karena proses oksidasi. Lensa mata pada pasien diabetes lebih rentan mengalami stres oksidatif karena terganggunya kapasitas antioksidan. Superoksida dismutase adalah enzim antioksidan paling utama pada lensa mata yang mendegradasi radikal superoksida $\left(\mathrm{O}_{2}{ }^{-}\right)$ menjadi hidrogen peroksida $\left(\mathrm{H}_{2} \mathrm{O}_{2}\right)$ dan oksigen. Beberapa studi menunjukan stres osmotik pada lensa dihasilkan karena akumulasi sorbitol menyebabkan apoptosis pada epitel lensa dan membentuk katarak (Pollreisz \& Schmidt-erfurth, 2010).

\section{KESIMPULAN}

Katarak merupakan keadaan dimana lensa mata mengalami penurunan transparansi atau peningkatan kekeruhan. Mekanisme utama yang mendasari perkembangan katarak adalah terjadinya modifikasi, agregasi, dan presipitiasi kristalin. Penyakit sistemik merupakan salah satu faktor risiko katarak. Risiko terjadinya katarak dapat meningkat sebanyak 5 kali lebih besar bila seseorang menderita diabetes melitus.

Mekanisme diabetes melitus tipe 2 dalam meningkatkan risiko terjadinya katarak adalah melalui jalur poliol. Produksi sorbitol yang dikatalisis oleh enzim aldose reduktase (AR) pada pasien diabetes lebih cepat dibandingkan dengan banyaknya sorbitol yang dikonversi menjadi fruktosa, dan pengeluaran sorbitol yang terhambat karena sifat polar sorbitol meningkatkan akumulasi sorbitol intraseluler yang menyebabkan efek hiperosmotik dan menghasilkan degenerasi lensa yang membentuk katarak. selain itu, stres osmotik yang terjadi karena akumulasi sorbitol menyebabkan stres pada retikulum endoplasma yang pada 
akhirnya akan membentuk radikal bebas yang merusak serat lensa.

\section{DAFTAR PUSTAKA}

American Diabetes Association. (2010). Diagnosis and classification of diabetes mellitus. Diabetes Care, 33(1), 562-569.

Chew M, Chiang PP, Zheng Y, Lavanya R, Wu R, Saw SMEI, Lamoureux EL. (2012). The Impact of Cataract, Cataract Types, and Cataract Grades on Vision-Specific Functioning Using Rasch Analysis. Am J Ophthamol, (154), 29-38.

Fatimah RN. (2015). Diabetes Melitus Tipe 2. Majority, 4(5), 93-101.

Gupta VB, Rajagopala M, \& Ravishankar B. (2019). Etiopathogenesis of cataract: An appraisal. Indian Journal Of Ophthalmology, 62(2), 103-109.

Hadini MA, Eso A, \& Wicaksono S. (2016). Analisis faktor risiko yang berhubungan dengan kejadian katarak senilis di RSU Bahteramas tahun 2016, 3(2), 256-267.

Ilyas S, \& Yulianti S. (2017). Ilmu penyakit mata. Jakarta: Badan Penerbit Fakultas Kedokteran Universitas Indonesia.

Kementrian Kesehatan Republik Indonesia. (2014). Situasi Gangguan Penglihatan dan Kebutaan.

Kiziltoprak, H., Tekin, K., Inanc, M., \& Goker, Y. S. (2019). Cataract in diabetes mellitus. World Journal of Diabetes, 10(3), 140-153.

Lam D, Rao SK, Ratra V, Liu Y, Mitchell P, King J, Chang DF. (2015). Cataract. Nature Reviews, 1(15014), 1-15.

Liu Y, Wilkins M, Kim T, Malyugin B, \& Mehta JS. (2017). Cataracts, 390(390), 600-612.

Nadyanti F, Himayani R, Putri GT, \& Yusran M. (2019). Hubungan durasi menderita diabetes melitus tipe 2 dengan kejadian katarak di RSUD DR. H. Abdul Moeloek Provinsi Lampung Tahun 2018. Essence of Scientific Medical Journal, 17(1), 1-4.

Nartey A. (2017). The pathophysiology of cataract and major interventions to retarding its progression: a mini review. MedCrave, 6(3), 4-7.

Pollreisz A, \& Schmidt-erfurth U. (2010). Diabetic cataract - pathogenesis, epidemiology and treatment. Journal of Ophthalmology.

Pradhevi L, Moegiono, \& Atika. (2012). Effect of type 2 diabetes mellitus on cataract incidence rate at ophthalmology outpatient clinic, dr soetomo hospital, surabaya. Folia Medica Indonesiana, 48(3), 137-143.

Rosyada A, \& Trihandini I. (2013). Determinan komplikasi kronik diabetes melitus pada lanjut usia, 7(9), 395-401.

Song $\mathrm{P}$, Wang $\mathrm{H}$, Theodoratou $\mathrm{E}$, Chan KY， \& Rudan I. (2018). The national and subnational prevalence of cataract and cataract blindness in China: a systematic review and metaanalysis. Journal Of Global Health, 8(1), 1-18.

Sugiharto, Hsu YY, Toobert DJ, \& Wang ST. (2019). The validity and reliability of the summary of diabetes self-care activities questionnaire: an Indonesian version. INJEC, 4(1), 25-36. 